\title{
DEVELOPING NETWORKED ONLINE LEARNING DESIGNS AND ITS EFFECTIVENESS ON THE WORKS OF STUDENTS IN HIGHER EDUCATION: CASE STUDIES IN INDONESIA
}

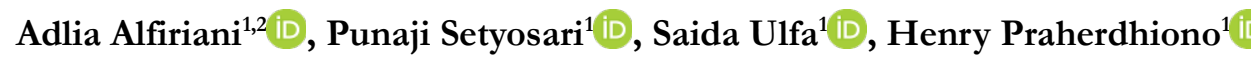 \\ ${ }^{1}$ Universitas Negeri Malang (Indonesia) \\ ${ }^{2}$ Universitas PGRI Sumatera Barat (Indonesia) \\ adlia.heldi@gmail.com, punaji.setyosari.fip@um.ac.id, saida.ulfa@gmail.com, henry.praherdhiono.jip@um.ac.id
}

Received December 2020

Accepted September 2021

\begin{abstract}
This study aims to develop a network design to meet the connection and interaction needs of students during the online learning process. The research and development method used in this research is divided into four stages, namely needs analysis, design, formative evaluation and revision. The results of the formative evaluation showed the learning design developed has a validity value of 90 out of a maximum score of 115 with a very valid category. This showed the design has good integrity and is feasible to be applied in online learning in higher education. The design also received a practicality value of 83 from a maximum of 165 in the very practical category, and the students gave a positive perception because they thought that the design could be easily followed in their online learning. The effectiveness test also shows that the network design is very effective for student work in online learning. This is evidenced by the difference in the average score of student work in the group using the learning network design and those using content-based and collaborative design. Furthermore, there were significant differences between those that used the network design and those that used the content-based design. However, there was no significant difference in student work results between the group using the network design and those using collaborative.
\end{abstract}

Keywords - Learning design, Online learning, Learning networked, Higher education.

\section{To cite this article:}

Alfiriani, A., Setyosari, P., Ulfa, S., \& Praherdhiono, H. (2022). Developing networked online learning designs and its effectiveness on the works of students in higher education: Case studies in Indonesia. Journal of Technology and Science Education, 12(1), 4-20. https://doi.org/10.3926/jotse.1189

\section{Introduction}

Currently the use of the internet continues to increase in universities and has popularized online learning (Swan, 2019). While Wu, Liu, Qiu and Liu (2016) reported that most students spend their time online to acquire knowledge. Furthermore, Allen and Seaman (2016) also states that about 30\% of students in college have signed up for at least one online course and this has the likelihood of increasing in subsequent years. In line with this, higher education institutions seek to increase online learning capacity through the use of various platforms such as video conferencing and LMS. However, there are no 
mandatory standards regarding online learning and this allows institutions and individuals to choose the desired method which leads to significant variations while some others dislike using technology. Another problem observed is the absence of a suitable learning design which has been reported to be a success factor in online learning (Bates \& Sangrà, 2011) and a means of achieving more effectiveness (Khodabandelou \& Samah, 2012) in online learning courses. According to Moreira-Mora \& Espinoza-Guzmán (2016), learning design is the main strategy to ensure the quality of higher education. However, according to Chen (2016), poorly designed online learning leads to confusion, lack of focus and direction, frustration, and an inability to time communication.

Research conducted to develop online learning designs to ensure the effectiveness of learning interactions in tertiary institutions is still very rare. Meanwhile, several studies have reported lack of interaction to be one of the factors causing student failure and eventual dropping out of online courses (Willging \& Johnson, 2019; Zielinski, 2000). In addition, Fortune, White, Jugdev and Walker (2011) also reported that learning interaction is one of the three main aspects of online knowledge acquisition. This is known because the availability of large resources causes difficulty in filtering the information needed (Wu et al., 2016). According to Borup, West and Graham (2012), online learning has caused uncertainty in the quality and frequency of interactions between students.

According to Donmez, Simsek and Arikan (2010) and Durak, Cankay, Yunkul and Ozturk (2017) interactions in online learning design currently occur more frequently in students with content and tend to facilitate independent learning. However, this is less relevant to the competency standards of higher education graduates in the industrial era 4.0 which require mastery of 21 st century skills such as communication, collaboration and innovation. Higher education requires complex interactions because all resources have a special role and contribution in the process of building knowledge. Meanwhile Baig (2011) states that students should be allowed to connect and interact with online content and also be given space to share knowledge and collaborate with peers. This is expected to assist in the production and creation of the necessary skills (Durak et al., 2017). However, one method of creating this complex interaction in online learning is through the use of a networks.

According to Bouchard (2013); Poell, Chivers, Van Der Krogt and Wildemeersch (2000), using learning networks allowed students to acquire knowledge in new dimensions. Also, the use of networks support lifelong learning (Garcia, 2014; Jaldemark \& Öhman, 2020). According to Hodgson and McConnell (2019), it was stated that network learning emerged and developed historically as a pedagogical response to increase the number of online learning programs and implementations. Furthermore, according to Networked Learning Editorial Collective (NLEC) (2020), it was stated that the use of learning networks is a step towards the manifestation of online education that is increasingly cheap. The concept of learning networks was first popularized by Van der Krogt in 1995 as an organizational system that requires its members to carry out certain activities and processes to achieve organizational goals (Poell et al., 2000). However, currently it is being implemented in the field of education through the integration of internet technology to support online learning. The same thing was expressed by Czerkawski (2016) that the learning network is a learning model that is mediated by internet technology to facilitate interaction between humans, content, resources, and tools. In addition, Anders (2018) also shows that learning networks provide certain benefits in terms of mastery of experiences, variations in learning, and effective persuasion and social unity for students.

Several studies have been conducted on the effect of using this network on student performance. For example, Anders (2018) shows that it is able to promote student independence in social networks. Meanwhile Durak et al (2017) reported its effect on students' general performance. Apart from that, they were also found to have the ability to help their collaboration skills (Lelasari, Setyosari \& Ulfa, 2017; Siemens, 2004.). There is currently no network learning design confirmed and recognize to have the capability to increase student academic achievement (Czerkawski, 2016), especially by facilitating interaction in online learning for students in higher education. Some studies conducted on this concept only provide a report on designs with simple and separate connections and interactions, such as personal, 
social, and professional learning networks. However, an effective learning network design has not been found (Czeweski, 2016; Hodgson \& McConnaill, 2019), especially those that facilitate complex interactions between students, devices, teachers, and professional experts.

Based on the above explanation, this study aims to:

1. Develop networked online learning designs with complex connections and systematic interactions, as well as effective for students in higher education

2. Know the validity level of networked online learning designs by experts

3. Know the practicality level of networked online learning designs by students

4. Know the effectiveness of networked online learning designs on student work results

\section{Literature Review}

\subsection{Connectivity in Learning Networks}

According to Jones (2015), networks are related to the relationship graphs and representations of several objects connected by links also known as nodes. Meanwhile, according to Siemens and Tittenberger (2009), knowledge and learning can be explained as networks at three levels including nerve, conceptual, and external. The node is a neuron at the nerve level, mind at the conceptual level, and a person serving as the source of information or entity with the ability to connect to the internet at the external level. One of the simple examples at the external level is the perception of students as a node in real or virtual social networks with the relationship with classmates or teachers observed as a connection. Further recent literature by Networked Learning Editorial Collective (NLEC) (2020) suggested that learning networks promote the relationship between people, learning sites and actions, ideas, resources, as well as solutions across time, space and media.

Learning networks are presently defined as the models mediated by technology to facilitate the interaction between people, content, resources, and tools (Czerkawski, 2016). The key term in this definition is the connection and the emphasis on interactions between people mediated by technology and resources. The concept has been associated with the theory of connectivity by recent studies (AlDahdouh, 2018).

The theory of connectivity assumes the formation of knowledge has structures in the form of networks and that the connection of students with other resources usually leads to a collaborative interaction. This, therefore, means learning is a process of network formation and the ability of more students to connect to one resource provides a better position in the learning network due to the easy and faster flow of information.

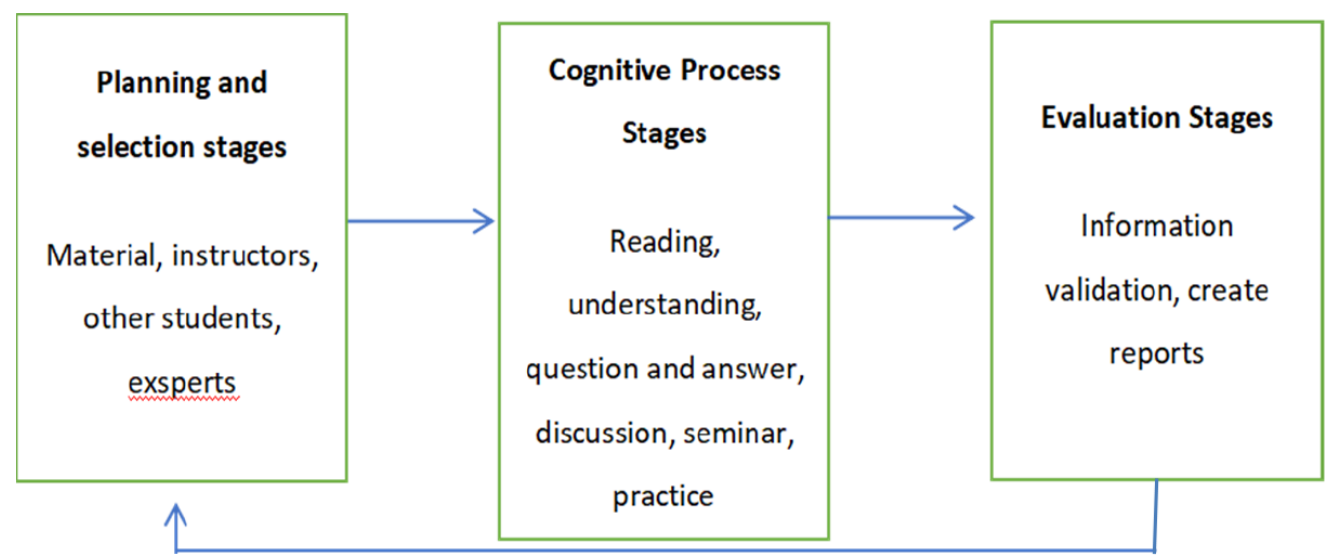

Figure 1. Stages of Connectivity in online learning networks 
According to AlDahdouh (2018), there are three stages in the formation of student connections in the learning network and they include planning and selection cognitive processes, and evaluation. The planning stage involves the selection of appropriate resources to provide the knowledge needed by students to complete their assignments. The cognitive aspect involves the process of interacting with the resources selected while the evaluation phase is concerned with the monitoring of the selected resources and deciding on whether or not to use them. However, if the decision made was not to use them, the process would be repeated from the planning stage. The selection of resources in the learning network has been expressed by students to be dependent on self-efficacy and worthiness of resources. The stages are, therefore, presented in Figure 1.

The principles of connectivity have been explained by Siemens (2004) to include learning and knowledge-based on diverse opinions, learning defined as the process of connecting specific nodes or information sources and its ability to stay on non-human equipment, desire to know more, fostering and maintaining connections for continuous learning, ability to see relationships between fields, ideas and concepts, as well as the renewal of knowledge as a learning goal, and independent decision-making process.

\subsection{Learning Networks and Interactions}

According to AlDahdouh (2018), the formation of connections in learning networks occurs in three stages, namely planning and thinking, cognitive processes, and evaluation. Interaction is the activity that is mostly observed at the cognitive process stage because of the communication between students to find solutions to the assignment given by the teacher. If the resource chosen at the planning stage is a book, then reading and understanding of the content is carried out at this stage and if people are selected, a discussion is also carried out. This stage often takes longer than the other two stages and this makes interaction an important factor in achieving learning goals (Wei, Peng \& Chou, 2015).

Besides Hebert (2018) has categorized student interactions in online learning into three, namely student interaction with students, instructors, and content. Several studies have also reported that a combination of these interactions is reported to increase motivation, satisfaction, and achievement in online courses. Furthermore, Hiltz and Turoff (2002) show that the effectiveness of learning networks is largely determined by the development of various aspects of interaction during online learning. For example, teachers are expected to play the same role they would play in a conventional classroom on this platform by rapidly building trust in students in the first few weeks of the course. It is possible to achieve this through the delivery of lecture orientation, learning objectives, and outcomes followed by individual student assignments and responsibilities, and subsequently lesson content. Furthermore, interaction between students can be developed through collaborative learning activities carried out in groups to discuss or share knowledge and comment on assignments to jointly produce effective results.

Meanwhile, student interaction with the device can be developed through active participation, especially with the use they are considered most familiar with. This involves designing notification and quiz routines for self-testing and mastery learning as well as ensuring the possibility to post video, audio, PowerPoint presentations, and hypertext material on the software. It should also be designed to support synchronous, asynchronous or both forms of communication during the learning process (Goodyear, Jones, Asensio, Hodgson \& Steeples, 2005). In addition, according to Anders (2018) student interaction with professional experts can be carried out by mastery of experience activities involving professionals and being involved in the professional community.

According to Durak (2017), students develop when they are in a learning network, this can be seen from the formation of a simple network characterized by connections and interactions between students, teachers, and content at the beginning of the meeting and the involvement of professional resources at the end of the meeting. this results in a more complex and ultimately stronger network. The interaction pattern in the learning network can be seen in Figure 2. 


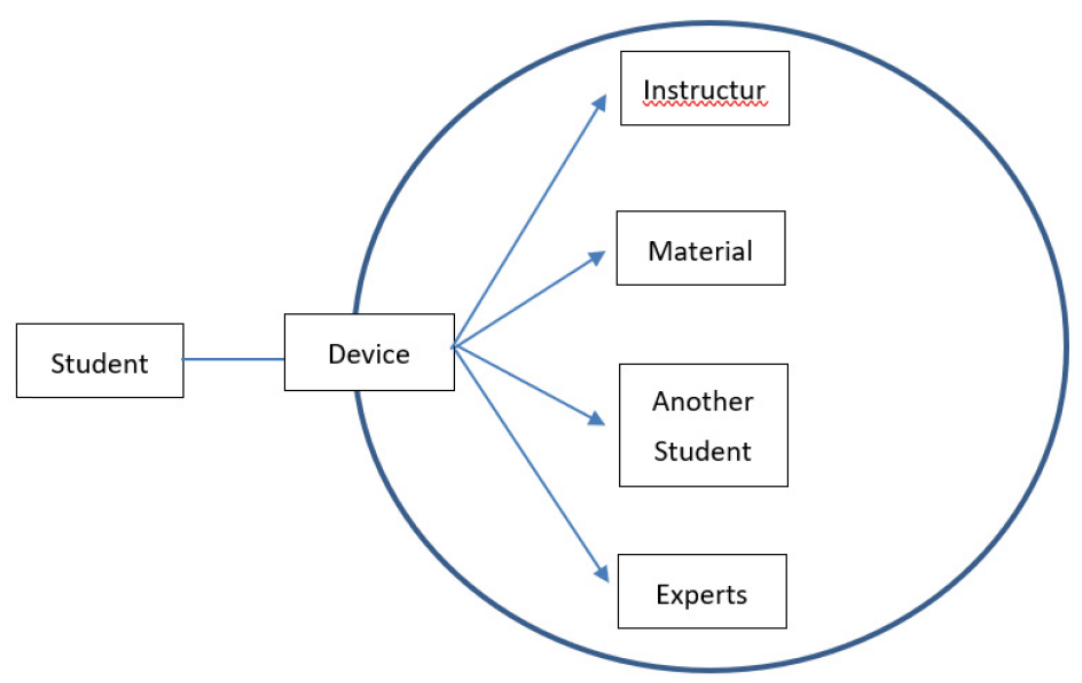

Figure 2. Patterns of interaction in the learning network

\section{Materials and Methods}

This research was carried out using the development method, which is a systematic tool that assists learning designers to design, develop and evaluate learning programs, processes and products in accordance with the criteria of internal consistency and effectiveness (Richey, 1994). According to Akker, Gravemeijer, Mckenney and Nieveen (2006) development research is divided into formative and reconstructive studies. This research type is more related to formative studies with the use of exploratory to evaluation studies during the development process. Therefore, the process of developing a networkbased online learning design is carried out from exploratory studies with preliminary activities used to identify student learning needs, as well as the technique required to determine and analyze related literature to produce initial prototypes. Furthermore, an evaluation study is carried out through formative assessment and revised to obtain the final prototype.

Furthermore, Akker et al. (2006) also stated the importance of quality criteria in formative evaluation, which aims to increase interventions for the product developed, through validity, practicality and effectiveness tests (Plomp \& Nieveen, 2013). Validity means that the product was built with the correct concepts and has internal consistency for each component. This is obtainable from experts with relevant skills regarding the product. Meanwhile, the ability to have practical value means that the developed learning design is easy for students to follow in accordance with their individual perceptions. Finally, having an effectiveness value means that the developed design can help students achieve their individual learning objectives.

\subsection{Research Procedure}

This network-based online learning design was produced using the adapted of research and development methods by Akker et al. (2006) and evaluated in four stages, namely preliminary activities, design, evaluation and revision. The activities carried out at each stage are shown in Figure 3.

The activities carried out at the needs analysis stage include reviewing articles related to online learning to ascertain strengths, weaknesses, and opportunities. In contrast, the initial prototype design stage was carried out by reviewing and analyzing literature on learning networks and making initial prototypes. Furthermore, in the formative evaluation stage, three activities were carried out, namely testing the validity of the initial prototype by validators who have relevant areas of expertise. The initial prototype was revised according to the validator input. Subsequently, a practical test was carried out on students in small groups to obtain the final prototype. The last stage tested the final prototype effectiveness on the results of student work and compare it with the group work using other online learning designs. 


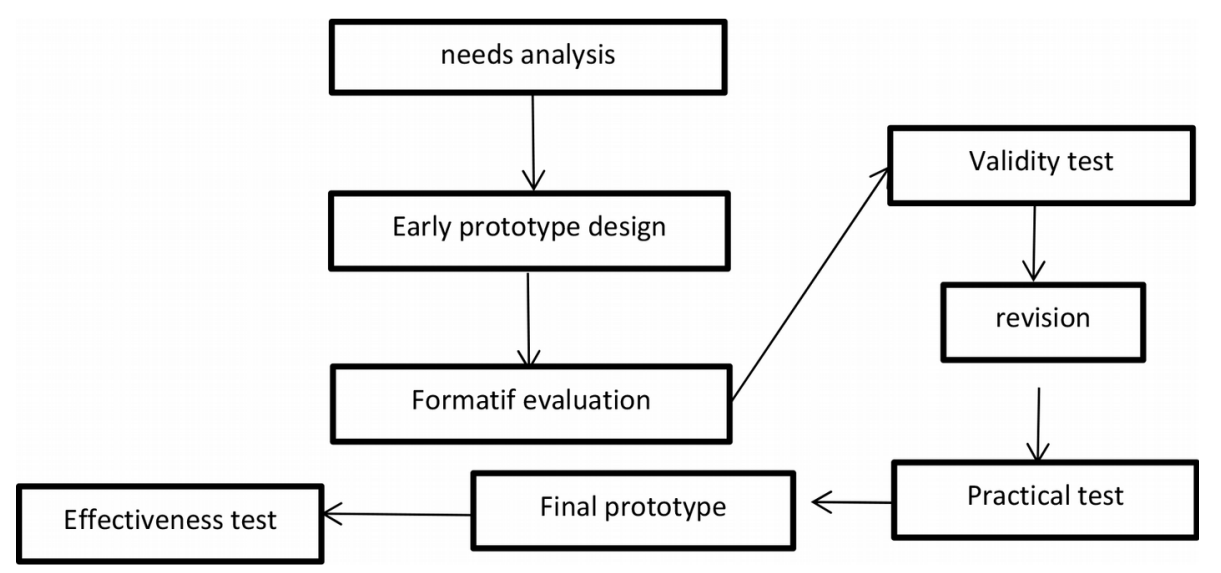

Figure 3. The stages of Research Development (Akker et al., 2006)

\subsection{Participants}

In this study, the participants were needed at the formative assessment stage. Meanwhile, the experts with relevant fields were engaged to validate the initial prototype of the networked online learning design. At the same time, students were involved in testing the practicality and effectiveness of the final design. Four validators were engaged in this study, as shown in Table 1.

Ten students who took curriculum development courses in the semester of 2019-2020 at the Education Technology study program, State University of Malang, were randomly selected. This aims to test the final prototype practicality of the developed design. Furthermore, 52 students in the same program were involved in the effectiveness test. The students were divided into three groups, namely the group that used the final prototype of the networked online learning design, those that used the content-based design, and those that used the collaborative design.

\begin{tabular}{|c|c|c|c|}
\hline Participant & Position & Teaching Field & Expertise \\
\hline 1 & Professor & Electrical engineering & Online and mixed learning \\
\hline 2 & Professor & Education technology & Learning Design \\
\hline 1 & Associate Professor & Education technology & Learning Media \\
\hline
\end{tabular}

Table 1. Experts Used for the Validation of the Network-Based Online Learning Design

\subsection{Research Instrument}

Research instruments were used to obtain data for formative assessments before passing validity judgments by the supervisor. Therefore, the instruments used in this development research are as follows:

1. Validation questionnaire sheet: This tool is used to determine the validity level of the developed network-based online learning design. Consists of 23 statement items, with 3 indicators and 7 sub-indicators. The first indicator is online learning with a sub-indicator model or pedagogic construct, learning strategies and technology. The second indicator is a learning network with sub indicators of connectivity, interaction and learning patterns. Meanwhile, the third indicator is the overall picture of the design. There are five alternative answer choices, namely strongly agree (5), agree (4), sufficiently (3), disagree (2) and strongly disagree (1). There were four validators, two were learning technology experts from Yogyakarta State University (UNY) and two were curriculum and learning technology expert from Padang State University (UNP). The same validation instrument sheet was given to all validators in one round. For the two validators at UNY, filling out validation instruments through face-to-face interviews were conducted on February 28, 2020. Meanwhile, the two validators from UNP were conducted online via email on 1 march, 2020. 
2. Practicality questionnaire sheet: This tool is to determine the practical value of the developed network-based online learning design. It consists of 33 question items related to the ease of use of the design along with its benefits. This study also consists of 5 alternative answer choices, namely strongly agree (5), agree (4), sufficiently (3), disagree (2) and strongly disagree (1). Practicality questionnaire sheets were distributed online to 6 students on April 14, 2020.

3. Assessment sheet for work: This tool is used to determine the effectiveness of the network-based online learning design developed on student work. This sheet was used in three groups, namely those that used the final prototype of the networked online learning design, those that used the content-based design, and those that used the collaborative design. As for the work of students examined in this study, it was a "study program evaluation proposal". Assessment indicators are related to originality, application of concepts, and systematics of writing and language. Each indicator has a maximum value of 25 points so the total score is 100 points. Student work was checked by a lecturer in charge of the Study Program Evaluation of Educational Technology Study Program, State University of Malang in June 2020.

\subsection{Data Analysis Technique}

The data analysis techniques were used to process the results of the validation test, as well as the practicality and effectiveness tests for further interpretation.

\subsubsection{The Analytical Techniques for Validation and Practicality Tests}

At this stage, the validation data obtained from 4 experts and practicality data acquired from 6 students were analyzed using descriptive statistical methods with the following steps:

1. Calculate the total score for each statement item.

2. Calculate the validity and practicality values by dividing the number of scores by the maximum score multiplied by $100 \%$ (Arikunto, 2008).

3. Interpret the amount of validity and practicality by analyzing Table 2, adaptation from Sudjana and Rivai (2001)

\begin{tabular}{|c|c|c|c|}
\hline No & Achievement Level & Validity Category & Practicality Category \\
\hline 1 & $90-100$ & Very valid & Very Practical \\
\hline 2 & $80-89$ & Valid & Practical \\
\hline 3 & $65-79$ & Quite valid & Quite Practical \\
\hline 4 & $55-64$ & Less valid & Less Practical \\
\hline 5 & $0-54$ & Invalid & Impractical \\
\hline
\end{tabular}

Table 2. Categories of validity, practicality and effectiveness assessments

\subsubsection{The Analytical Techniques for Effectiveness Test}

At this stage, the data on student work in the three groups were analyzed using the one-way ANOVA statistical method with the following steps:

1. Counting the number of scores obtained by students in both groups

2. Processing the scores of the three groups using the one-way ANOVA analysis technique on SPSS

3. Interpret the analysis results by comparing the average value of student performance in the three groups. It can also be seen by looking at the probability value in the sig column of the ANOVA analysis. Also, when the obtained values are less than or equal to 0.05 , it can be concluded that the online learning design network is effective on student performance. This is because there are significant differences in the performance results of the three groups. Conversely, when the value 
obtained is greater than 0.05 , then it can be concluded that there is no difference in performance results between the three groups. In addition, the post hoc follow-up tests were conducted to determine the groups with significant differences.

\section{Research Result}

\subsection{Needs Analysis}

Online learning allows students to acquire knowledge at a higher level, regardless of the time and location (Górska, 2016). According to Kvavik and Caruso (2005), students have at least one computer or smartphone connected to the internet for learning, social interaction, and entertainment. Meanwhile, Wu et al. (2016) showed some students spend their time studying online. However, online education tends to experience many challenges in its implementation, therefore, its effectiveness is low. This is in line with Chen (2016) that poorly designed online learning often confuses students, makes them lose focus, and frustrated. Also, according to Coman, Țîru, Meseşan-Schmitz, Stanciu and Bularca (2020), the lack of interaction and poor communication is a problem in online learning. Furthermore, Dhawan (2020) showed students feel online learning is often dull and unpleasant.

The design is one of the primary keys to successful online learning, with high relevance for students (Bao, 2020; Bates \& Sangra, 2011). According to Weerasinghe, Ramberg and Hewagamage (2009), it is the most important contributor to successful online learning. Meanwhile, according to Gopal, Singh and Aggarwal (2021), online learning design impacts satisfaction, which in turn affects student performance. Based on the findings of Bozkurt and Zawacki-Richter (2021), the design for distance learning has become the most studied in the last decade. However, the currently available designs do not facilitate complex and systematic connections and interactions. Students are more required to review content rather than work on projects or only e-learning. This aligns with Hebert (2018) that online learning designs currently only provide interaction between students and teachers or with their peers. However, interactions with professional experts are rare. The process is carried out separately from other learning interactions, which do not suit students' needs to develop their professional abilities. Therefore, it is essential to create a flexible design (Dhawan, 2020) that facilitates complex connections and interactions through a learning network model.

\subsection{Design: Early Prototype}

The online learning network design was developed from the synthesis of literature between network and online learning. Six kinds of literature were examined and analyzed to produce an initial prototype. The list of literature involved are seen in the Table 3.

\begin{tabular}{|l|l|}
\hline \multicolumn{1}{|c|}{ Identity } & \multicolumn{1}{c|}{ Scope } \\
\hline AlDahdouh (2018) & Formation of connections in the learning network \\
\hline Hiltz \& Turoff (2002) & Effective learning network in asyncronous \\
\hline Anders (2018) & Networked learning with professionals \\
\hline Risien (2019) & Actors in learning network \\
\hline Ardito (2018) & The emergence of student learning networks \\
\hline Carvalho \& Goodyear (2018) & Learning network design \\
\hline
\end{tabular}

Table 3. relevant literature in designing the initial prototype

The structure of student knowledge in online learning is formed through a network. The students can connect and interact with one or more nodes that contribute to the formation of their ability. The nodes can be people, and other sources of information that are also connected to the internet. The online learning network is systematically designed to the interaction of students with their device nodes, teachers, materials, colleagues, and professional experts through a synchronous and asynchronous communication. Also, connectivity is the key to each student's interaction in network-based online learning. This is built in three stages, namely planning, cognitive processing, and evaluation. For example, student interaction with 
the material at the planning stage allows them to choose the one that suits their task. After selecting the material, the next stage is the cognitive process, which enables them to read (text), watch, and listen (multimedia) to the material for proper understanding and completing the task. The students will decide whether to stay in the interaction or move on to another exchange. Also, the learning networks develop during online learning, ranging from superficial relationships and interactions to more complex ones at the end of the session.

In this design, the online learning process is grouped into three stages, namely orientation, core activities, and closing. In the orientation stage, students actively interact with the teacher's tools and content. Furthermore, the device allows them to study synchronously and asynchronously. It also allows them to use multiple devices such as smartphones, computers \& applications (LMS, social media, and video conferencing) to implement this design. The next stage allows them to build trust online, just like in a traditional classroom. Therefore, the teachers need to ensure students believe in the ability of online learning to benefit their academics. Subsequently, the students go through the interactive content.

In the core stage, they were divided into several groups consisting of 3-4 persons. The purpose of this grouping is to share knowledge about tasks and concepts built from previous interactions. After interacting with other students, they communicate with experts who provide adequate information to complete their assignments. This was done through a question and answer process, case study discussions, seminars, and virtual practice. The purpose of interaction with these experts was to validate prior knowledge and develop professional skills. Next is the evaluation stage, where students report their progress to the teacher, as well as provide feedback and make improvements. Finally, the students present their work in class, which the teacher, colleagues, and experts attend for further appreciation. The initial prototype can be seen in Figure 4.

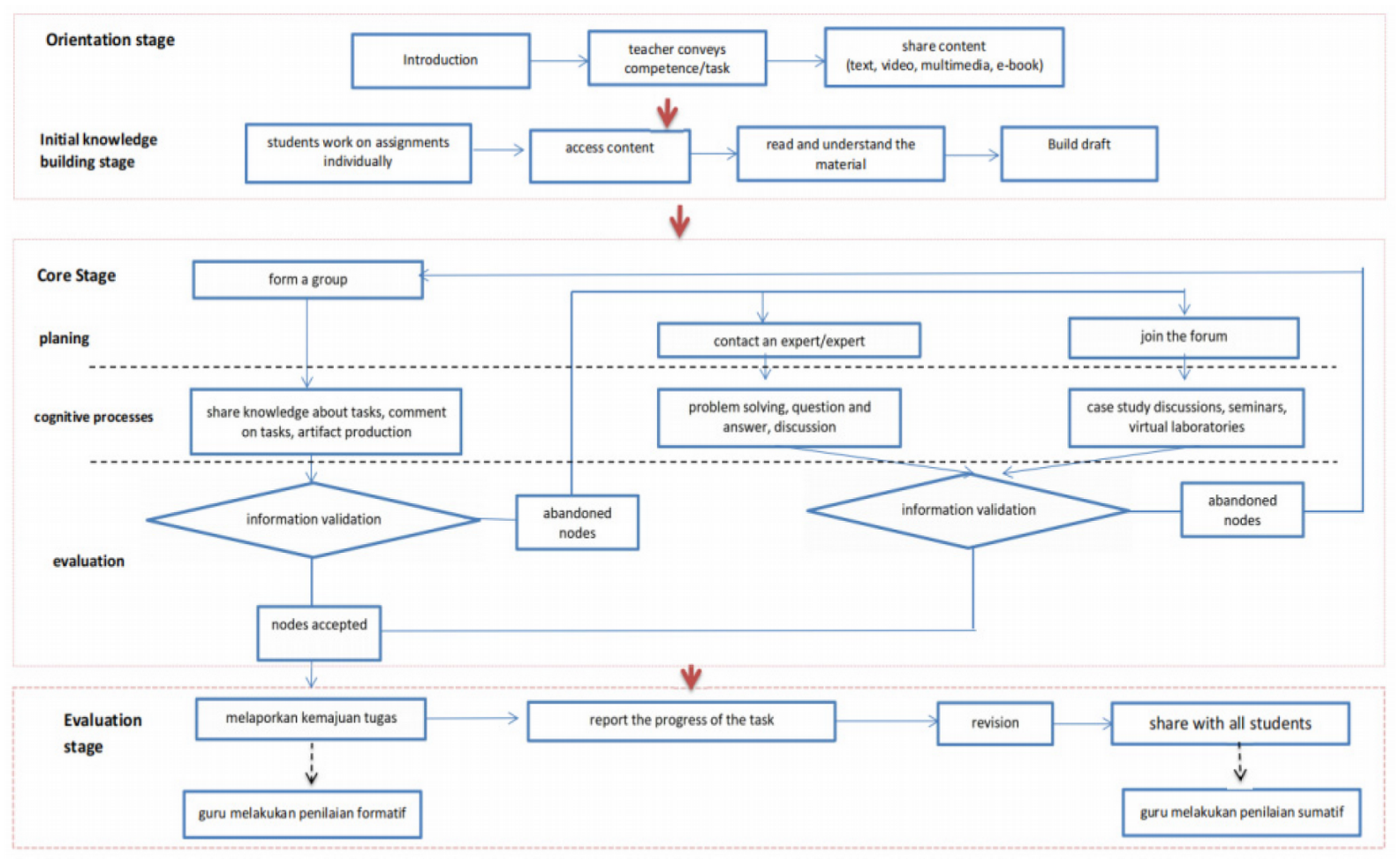

Figure 4. The Networked Online Learning Design Initial Prototype 


\subsection{Formative Evaluation}

\subsubsection{Validity Test}

Based on the Table 4, the scores of the total validation results for 4 validators, namely V1, V2, and V4 are 90,97 , and 90 in the very valid category, while V3 with a score of 82 is in the valid category with a total average score of 90 in the very valid category. These results indicate that the developed design is built with appropriate concepts, namely online learning, networks, connectivity and interactivity, with a good level of integrity. It also shows that all validators agree that network-based online learning design needs to be implemented for students in higher education.

\begin{tabular}{|c|r|r|r|c|}
\hline Validator & Assessment Score & Maximum Score & Total Validation Results & Assessment Category \\
\hline 1 & 104 & 115 & 90 & Very Valid \\
\hline 2 & 111 & 115 & 97 & Very Valid \\
\hline 3 & 94 & 115 & 82 & Valid \\
\hline 4 & 104 & 115 & 90 & Very Valid \\
\hline \multicolumn{3}{|c|}{ Total } & 359 & Very Valid \\
\hline
\end{tabular}

Table 4. Recapitulation of validation results for the development of network-based online learning design

\subsubsection{Practical Test}

Table 5 shows that the total practicality obtained from P1, P4, P5, and P8 are 76, 79, 73 and 79 in a quite practical category, while P2, P3, P6, P7 and P10 are 83, 88, 85, 88 and 82 in a practical category. Finally, P9 has a very practical category score of 94 , while the average overall score is 82.7 in a practical category. These results indicate that the learning network-based design developed is practical easily followed by students in online learning.

\begin{tabular}{|c|r|r|r|c|}
\hline $\begin{array}{c}\text { Participants's } \\
\text { Number }\end{array}$ & Assessment Score & Maximum Score & $\begin{array}{c}\text { Total Practicality } \\
\text { Results }\end{array}$ & Rating Category \\
\hline 1 & 125 & 165 & 76 & Pretty practical \\
\hline 2 & 137 & 165 & 83 & Practical \\
\hline 3 & 146 & 165 & 88 & Practical \\
\hline 4 & 130 & 165 & 79 & Pretty practical \\
\hline 5 & 121 & 165 & 73 & Pretty practical \\
\hline 6 & 141 & 165 & 85 & Practical \\
\hline 7 & 146 & 165 & 88 & Practical \\
\hline 8 & 130 & 165 & 79 & Pretty practical \\
\hline 9 & 155 & 165 & 94 & Very practical \\
\hline 10 & 136 & 165 & 82 & Practical \\
\hline \multicolumn{2}{r|}{} & & 827 & \\
\hline & Total & 83 & Practical \\
\hline
\end{tabular}

Table 5. Summary of practicality results for the development of network-based online learning design

\subsubsection{Revision}

Revision of the initial prototype was carried out based on suggestions from the validator, hence it becomes the final. Also, changes were only made to evaluate activities contained in the core stage. At first, the evaluation of student-student interactions was carried out by deciding whether it helped them complete the task. The validator suggested that evaluation activities do not need to stay or leave the 
interaction but can be replaced by asking students to make reports about the results. Hence, all the students can interact with the experts. The final prototype can be seen in Figure 5.

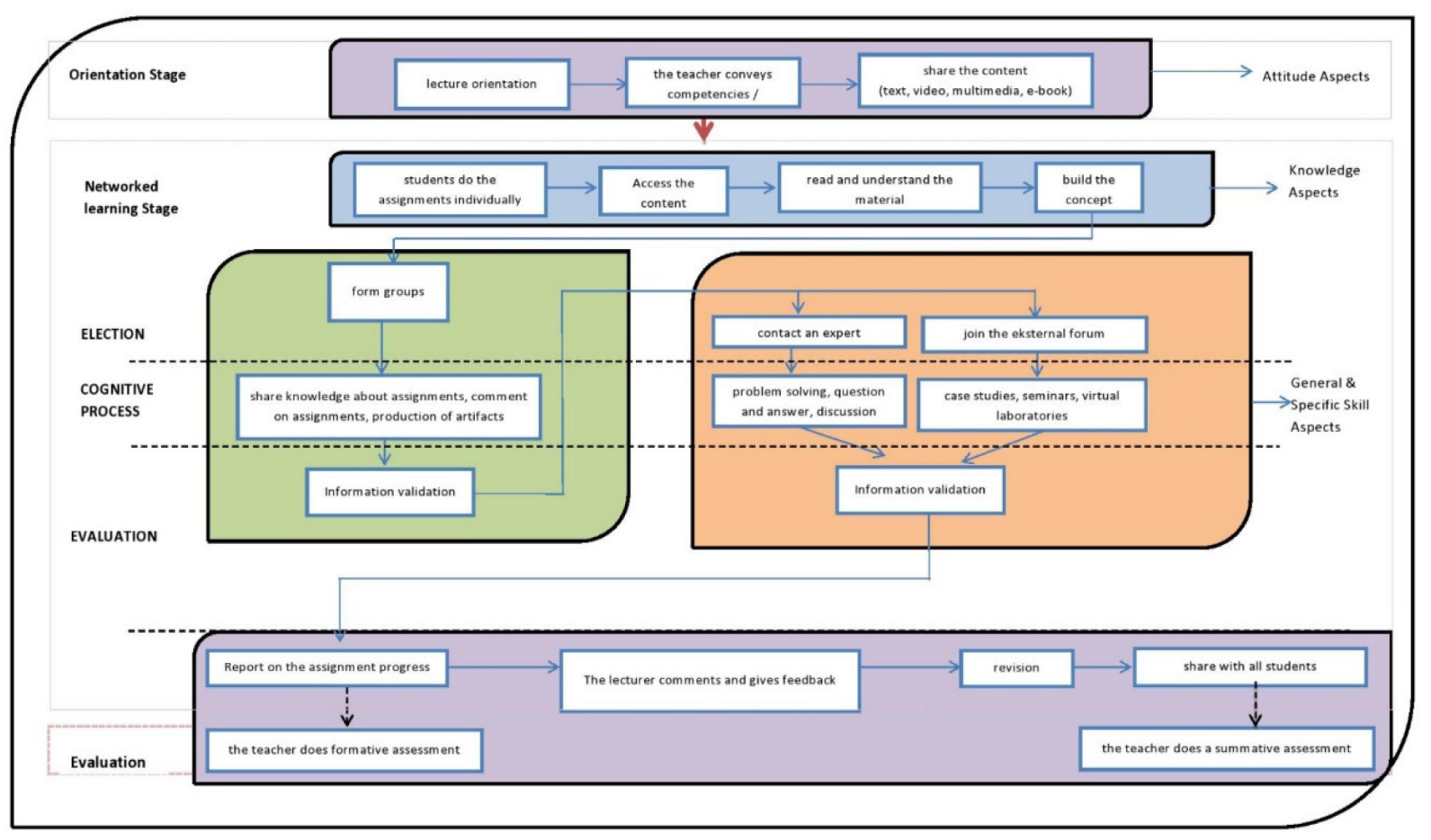

Figure 5. Final prototype of the online learning network design

\subsubsection{Effectiveness Test}

\begin{tabular}{|c|c|c|c|c|c|}
\hline & $\begin{array}{c}\text { Group of students } \\
\text { using the } \\
\text { networked online } \\
\text { learning design } \\
\text { final prototype }\end{array}$ & Participants's & $\begin{array}{c}\text { Group of } \\
\text { students using } \\
\text { content-based } \\
\text { online learning } \\
\text { design }\end{array}$ & Participants's & \multicolumn{2}{|c|}{$\begin{array}{c}\text { Group of } \\
\text { students using } \\
\text { collaborative } \\
\text { online learning } \\
\text { design }\end{array}$} \\
\hline 1 & 92 & 1 & 70 & 1 & 85 \\
\hline 2 & 80 & 2 & 85 & 2 & 80 \\
\hline 3 & 75 & 3 & 73 & 3 & 70 \\
\hline 4 & 79 & 4 & 70 & 4 & 77 \\
\hline 5 & 85 & 5 & 85 & 5 & 83 \\
\hline 6 & 80 & 6 & 80 & 6 & 65 \\
\hline 7 & 95 & 7 & 75 & 7 & 75 \\
\hline 8 & 93 & 8 & 70 & 8 & 70 \\
\hline 9 & 88 & 9 & 80 & 9 & 70 \\
\hline 10 & 80 & 10 & 70 & 10 & 80 \\
\hline 11 & 75 & 11 & 60 & 11 & 77 \\
\hline 12 & 70 & 12 & 70 & 12 & 75 \\
\hline 13 & 82 & 13 & 83 & 13 & 70 \\
\hline 14 & 78 & 14 & 80 & 14 & 80 \\
\hline 15 & 75 & 15 & 75 & 15 & 75 \\
\hline 16 & 80 & 16 & 77 & 16 & 77.05 \\
\hline 17 & 95 & 17 & 75 & 17 & 18 \\
\hline
\end{tabular}

Table 7. The recapitulation of student performance results 
Before the work data were analyzed using the one-way ANOVA technique, they were tested for normality and homogeneity. The normality and homogeneity test results are seen in Tables 8 and 9 .

Based on the analysis results above, it is known that the data are normally distributed and homogeneous because of a sig value $>0.05$. Furthermore, a one-way ANOVA analysis was carried out using the SPSS program. The result is seen in the Table 10.

Based on the table above, the probability value in the sig column is 0.008 , which is less than 0.05 . This means there are differences in student learning outcomes in the three groups. The Post Hoc follow-up tests were also conducted to determine which groups had significant differences. Therefore, it is known that the results of student group work using networked online learning designs are significantly different from the effects of group work using content-based designs. Meanwhile, the results using collaborative online learning designs were substantially different from those using content-based designs. However, no significant difference was found between the performance results of the group who used networked and those who used collaborative designs.

\begin{tabular}{|l|r|}
\hline \multicolumn{2}{|c|}{ One-Sample Kolmogorov-Smirnov Test } \\
\hline & Performance result \\
\hline $\mathrm{N}$ & 52 \\
\hline Kolmogorov-Smirnov Z & 1.108 \\
\hline Asymp. Sig. (2-tailed) & .172 \\
\hline a. Test distribution is Normal. & \\
\hline
\end{tabular}

Table 8 . The data normality test results

\begin{tabular}{|c|c|c|c|}
\hline \multicolumn{4}{|c|}{ Test of Homogeneity of Variances } \\
\hline Performance result & & & \\
\hline Levene Statistic & df1 & df2 & Sig. \\
\hline .793 & 2 & 49 & .458 \\
\hline
\end{tabular}

Table 9. The data homogeneity test result

\begin{tabular}{|l|r|r|r|r|r|}
\hline \multicolumn{2}{|c|}{ ANOVA } & & \\
\hline Performance result & Sum of Squares & df & Mean Square & \multicolumn{1}{c|}{ F } & Sig. \\
\hline Between Groups & 489.023 & 2 & 244.511 & 5.326 & .008 \\
\hline Within Groups & 2249.650 & 49 & 45.911 & & \\
\hline Total & 2738.673 & 51 & & & \\
\hline
\end{tabular}

Table 10. The One-way ANOVA analysis results

\section{Discussion}

The purpose of this study is to develop a network design that is valid, practical, and effective on the results of student work in online learning. The development of network design is a pedagogical innovation in making student online learning more meaningful because it can facilitate systematic connections and interactions between students and devices, students with teachers, students with content, students with students, and students with experts. Relationships can make learning networks more effective because the flow of information to and from students is easier and faster. Meanwhile, systematic interaction can help students to gain knowledge management and meaningful experiences in online learning. Several studies reveal that student-student interactions can create social experiences and hone collaborative skills. In contrast, student-content interaction can produce cognitive experience, then student-teacher interaction can make attitude experience, while student interaction with devices can 
increase their creativity and innovation in learning. Learning. In addition, interactions with professional resources provide opportunities that motivate, inspire, and create continuity between academic education and lifelong learning for professional development (Anders, 2018; Belawati, 2019; Trust, Carpenter \& Krutka, 2017).

Several studies showed the benefits of using networks in online learning (Anders, 2018; Durak, 2017). However, this study differs from others that focus on social (As'at, Setyosari \& Ulfa, 2017), personal (Issa, El Ghalayini, Shubita \& Abu-Arqoub, 2014), and professional learning network designs (Trust, 2012; Yokuş \& Yanpar-Yelken, 2019). The development of this design focuses on how to collaborate the connections and interactions of existing structures and make them complex and systematic. This aims to meet the needs of online learning students. These interactions are between students and devices, teachers, content, peers, and experts. This aligns with Anders (2018) that students develop in a learning network, starting from simple connections and interactions at the meeting to more complex at the end of the session. Meanwhile, Hirumi (2002) suggested that systematic interaction makes students' online learning more meaningful. In addition, the procedure in this study can be a reference for other designers to develop similar designs and break Carlvaho and Goodyear (2018) statement that learning networks might be challenging to design.

The findings in this study also reveal that the networked online learning design developed effectively affects student work in the educational technology study program at the State University of Malang (UM). It is known that the average score of student work in making proposals for evaluating learning programs in groups using the final prototype of the network design developed is better than the group of students using content-based online learning designs and also with groups of students using collaborative online learning designs. Furthermore, through one-way ANOVA analysis, it was found that significant differences only occurred between groups of students who used a content-based networked design and a contentbased collaborative design. Meanwhile, there was no significant difference between the groups of students who used the networked method and the groups who used the joint procedure. Several studies have shown that the design of learning networks has similarities with collaborative work (Issa et al., 2014). Also, the learning networks support students' collaborative skills, but learning and cooperative networks are two different things as stated by Downes (2010) that collaboration is formed based on shared interests.

\section{Conclusions}

The findings of this study showed the design of networked online learning has been developed through four stages, namely needs analysis, design, formative evaluation, and revision. This networked design has good integrity, and according to experts, it is very suitable for use in undergraduate programs at universities. This design contains stages of learning activities with systematic connections and interactions between students and devices, teachers, content, peers and experts that have never existed in a networked online learning design before. In addition, students' responses to this design were very positive, indicating that it was efficient and easy to follow. This study also suggested that the use of network design is effective on student performance in online learning, as seen from the significant difference in the results between the test groups. The performance results of the group of students using this design appear to be higher than the others. However, the limitation of this study is the small sample number of the effectiveness test, which limits the generalizability of the results. The scope of the analysis only focused on the results of student performance in undergraduate education programs and not on others. This will be a good follow-up work in the future. Finally, the results support the development of studies, especially the use of networks in online learning.

\section{Declaration of Conflicting Interests}

The authors declared no potential conflicts of interest with respect to the research, authorship, and / or publication of this article. 


\section{Funding}

The authors received no financial support for the research, authorship, and / or publication of this article.

\section{References}

Akker, J., Gravemeijer, K., Mckenney, S., \& Nieveen, N. (2006). Introducing educational design research. Educational Design Research, 3-7.

AlDahdouh, A.A. (2018). Jumping from one resource to another: How do students navigate learning networks? International Journal of Educational Technology in Higher Education, 15(1), 45.

https://doi.org/10.1186/s41239-018-0126-x

Allen, I.E., \& Seaman, J. (2016). Online report card: Tracking online education in the United States. Babson Park, MA: Babson Survey Research Group and Quahog Research Group. Available at: http://onlinelearningsurvey.com/reports/onlinereportcard.pdf

Anders, A.D. (2018). Networked learning with professionals boosts students' self-efficacy for social networking and professional development. Computers \& Education, 127, 13-29.

https://doi.org/10.1016/j.compedu.2018.08.009

Ardito, G.P. (2018). Emerging Student Learning Networks: Self- Directed Learning in an Eighth-Grade Life Science Classroom. Issues and Trends in Educational Technology, 6(1), 22.

https://doi.org/10.2458/azu_itet_v6i2_ardito

Arikunto, S. (2008). Prosedur Penelitian Suatu Pendekatan Praktik. Rineka Karya.

As'at, M. Setyosari, P., \& Ulfa, S. (2018). The development of eglish instructional design social learning network (SLN)-based using auction (interested based negotiation) strategy. JINOTEP, 4(1), 15-21. https://doi.org/10.17977/um031v4i12017p015

Baig, M.A. (2011). A Critical Study Of Effectiveness Of Online Learning On Students Achievement. IManager's Journal of Educational Technology, 7(4), 28-34. https://doi.org/10.26634/jet.7.4.1391

Bao, W. (2020). COVID -19 and online teaching in higher education: A case study of Peking University. Human Behavior and Emerging Technologies, 2(2), 113-115. https://doi.org/10.1002/hbe2.191

Bates, A.W., \& Sangra, A. (2011). Managing Technology in Higher Education: Strategies for Transforming Teaching and Learning. San Francisco: Jossey Bass.

Belawati, T. (2019). Pembelajaran Online (1st ed.). Universitas Terbuka.

Borup, J., West, R.E., \& Graham, C.R. (2012). Improving online social presence through asynchronous video. The Internet and Higher Education, 15(3), 195-203. https://doi.org/10.1016/j.iheduc.2011.11.001

Bouchard, P. (2013). Education Without A Distance: Networked Learning. Thompson Educational Publishing Inc. Toronto.

Bozkurt, A., \& Zawacki-Richter, O. (2021). Trends and Patterns in Distance Education (2014-2019): A Synthesis of Scholarly Publications and a Visualization of the Intellectual Landscape. The International Review of Research in Open and Distributed Learning, 22(2), 19-45. https://doi.org/10.19173/irrodl.v22i2.5381

Carvalho, L., \& Goodyear, P. (2018). Design, learning networks and service innovation. Design Studies, 55, 27-53. https://doi.org/10.1016/j.destud.2017.09.003

Chen, L.L. (2016). A Model for Effective Online Instructional Design. Literacy Information and Computer Education Journal, 7(2). https://doi.org/10.20533/licej.2040.2589.2016.0304 
Coman, C., Țîru, L.G., Meseşan-Schmitz, L., Stanciu, C., \& Bularca, M.C. (2020). Online Teaching and Learning in Higher Education during the Coronavirus Pandemic: Students' Perspective. Sustainability, 12(24), 10367. https://doi.org/10.3390/su122410367

Czerkawski, B.C. (2016). Networked learning: Design considerations for online instructors. Interactive Learning Environments, 24(8), 1850-1863. https://doi.org/10.1080/10494820.2015.1057744

Dhawan, S. (2020). Online Learning: A Panacea in the Time of COVID-19 Crisis. Journal of Educational Technology Systems, 49(1), 5-22. https://doi.org/10.1177/0047239520934018

Donmez, O., Simsek, Ö., \& Arikan, Y.D. (2010). How can we make use of learner interaction in online learning environments? Procedia - Social and Behavioral Sciences, 9, 783-787.

https://doi.org/10.1016/j.sbspro.2010.12.234

Downes, S. (2010). Learning networks and connective knowledge. In Collective intelligence and E-Learning 2.0: Implications of web-based communities and networking. IGI global. https://doi.org/10.4018/978-1-60566-7294.ch001

Durak, G. (2017). Using Social Learning Networks (SLNs) in Higher Education: Edmodo Through the Lenses of Academics. The International Review of Research in Open and Distributed Learning, 18(1). https://doi.org/10.19173/irrodl.v18i1.2623

Durak, G., Cankay, S., Yunkul, E., \& Ozturk, G. (2017). The Effects of A Social Learning Network On Students' Performances And Attitudes. European Journal of Education Studies, 3(3). 312-333. https://doi.org/10.5281/ZENODO.292951

Fortune, J., White, D., Jugdev, K., \& Walker, D. (2011). Looking again at current practice in project management. International Journal of Managing Projects in Business, 4(4), 553-572. https://doi.org/10.1108/17538371111164010

Garcia, D. (2014). Learning networks to enhance reflectivity: Key elements for the design of a reflective network. Revista de Universidady Sociedad Del Conocimiento (RUSC), 11(1), 32-48. https://doi.org/10.7238/rusc.v11i1.1736

Goodyear, P., Jones, C., Asensio, M., Hodgson, V., \& Steeples, C. (2005). Networked Learning in Higher Education: Students' Expectations and Experiences. High Educ, 50(3), 473-508. https://doi.org/10.1007/s10734-004-6364-y

Gopal, R., Singh, V., \& Aggarwal, A. (2021). Impact of online classes on the satisfaction and performance of students during the pandemic period of COVID 19. Education and Information Technologies. https://doi.org/10.1007/s10639-021-10523-1

Górska, D. (2016). E-learning in Higher Education. The Person and the Challenges. The Journal of Theology, Education, Canon Law and Social Studies Inspired by Pope John Paul II, 6(2), 35.

https://doi.org/10.15633/pch.1868

Hebert, A.D. (2018). Maximizing Interactivity in Online Learning: Moving Beyond Discussion Boards. Journal of Educators Online, 15(3), 26. https://doi.org/10.9743/jeo.2018.15.3.8

Hiltz, S.R., \& Turoff, M. (2002). What makes learning networks effective? Communications of the ACM, 45(4), 56. https://doi.org/10.1145/505248.505273

Hirumi, A. (2002). The Design and Sequencing of eLearning Interactions: A Grounded Approach. International Journal on E-Learning, 1(1), 19-27.

Hodgson, V., \& McConnell, D. (2019). Networked Learning and Postdigital Education. Postdigital Science and Education, 1(1), 43-64. https://doi.org/10.1007/s42438-018-0029-0 
Issa, G.F., El Ghalayini, H., Shubita, A.F., \& Abu-Arqoub, M.H. (2014). A Framework for Collaborative Networked Learning in Higher Education: Design \& Analysis. International Journal of Emerging Technologies in Learning (IJET), 9(8), 32. https://doi.org/10.3991/ijet.v9i8.3903

Jaldemark, J., \& Öhman, P. (2020). Developing a hybrid and networked educational approach to lifelong learning for organisations and employees. Proceedings for the Twelfth International Conference on Networked Learning (12, 47-50). Kolding, Denmark: Aalborg University. Available at: https://www.networkedlearning.aau.dk/digitalAssets/825/825871 11.-jaldemark---o-hman---developing-a-hybridand-networked-educational-approach-to-lifelong-learning-for-organisations-and-employees.pdf

Jones, C. (2015). Networked Learning. Springer International Publishing. https://doi.org/10.1007/978-3-319-01934-5

Khodabandelou, R., \& Samah, S.A.A. (2012). Instructional Design Models for Online Instruction: From the Perspective of Iranian Higher Education. Procedia - Social and Behavioral Sciences, 67, 545-552. https://doi.org/10.1016/j.sbspro.2012.11.359

Kvavik, R.B., \& Caruso, J.B. (2005). ECAR study of students and information technology, 2005: Convenience, connection, control, and learning. Boluder, CO: Educause Center for Applied Research. Available at: https://library.educause.edu/-/media/files/library/2005/10/ers0506w-pdf.pdf

Lelasari, M., Setyosari, P., \& Ulfa, S. (2017). Pemanfaatan social learning network dalam mendukung keterampilan kolaborasi siswa. Prosiding TEP \& Pds, 3(2). 167-172.

Moreira-Mora, T., \& Espinoza-Guzmán, J. (2016). Initial evidence to validate an instructional design-derived evaluation scale in higher education programs. International Journal of Educational Technology in Higher Education, 13(1), 11. https:// doi.org/10.1186/s41239-016-0007-0

Networked Learning Editorial Collective (NLEC) (2020). Networked Learning: Inviting Redefinition. Postdigital Science and Education, 3, 312-325. https://doi.org/10.1007/s42438-020-00167-8

Plomp, T., \& Nieveen, N. (2013). Educational design research. Part A: An introduction. SLO.

Poell, R.F., Chivers, G.E., Van Der Krogt, F.J., \& Wildemeersch, D.A. (2000). Learning-Network Theory: Organizing the Dynamic Relationships between Learning and Work. Management Learning, 31(1), 25-49. https://doi.org/10.1177/1350507600311004

Richey, R.C. (1994). Developmental Research: The Definition and Scope. Available at: https://eric.ed.gov/?id=ED373753

Risien, J. (2019). Curators and sojourners in learning networks: Practices for transformation. Evaluation and Program Planning, 73, 71-79. https://doi.org/10.1016/j.evalprogplan.2018.12.001

Siemens, G. (2004). Connectivism: A Learning Theory for the Digital Age. International Journal of Instructional Technology and Distance Learning (ITDL). Available at: http://www.itdl.org/Journal/Jan_05/article01.htm

Siemens, G., \& Tittenberger, P. (2009). Handbook of Emerging Technologies for Learning. Available at: https://pdfs.semanticscholar.org/c60b/3a6ff3bd457650afce80f18e5042ac6ac615.pdf? $\mathrm{ga}=2.189935789 .729162417 .1586150534-1146964821.1580782464$

Sudjana, N., \& Rivai, A. (2001). Media Pengajaran. Sinar Baru Algensindo.

Swan, K. (2019). Research on Online Learning. Online Learning, 11(1). https://doi.org/10.24059/olj.v11i1.1736

Trust, T. (2012). Professional Learning Networks Designed for Teacher Learning. Journal of Digital Learning in Teacher Education, 28(4), 133-138. https://doi.org/10.1080/21532974.2012.10784693 
Trust, T., Carpenter, J.P., \& Krutka, D.G. (2017). Moving beyond silos: Professional learning networks in higher education. The Internet and Higher Education, 35, 1-11. https://doi.org/10.1016/j.iheduc.2017.06.001

Weerasinghe, T., Ramberg, R., \& Hewagamage, K. (2009). Guidelines to Design Successful Online Learning Environments. Available at: https://www.researchgate.net/publication/257923909 Guidelines to Design Successful Online Learning Envir onments

Wei, H.C., Peng, H., \& Chou, C. (2015). Can more interactivity improve learning achievement in an online course? Effects of college students' perception and actual use of a course-management system on their learning achievement. Computers \& Education, 83, 10-21. https://doi.org/10.1016/j.compedu.2014.12.013

Willging, P.A., \& Johnson, S.D. (2019). Factors That Influence Students Decision to Droopout of Online Courses. Online Learning, 8(4). https://doi.org/10.24059/olj.v8i4.1814

Wu, H., Liu, Y., Qiu, L., \& Liu, Y. (2016). Research on network learning platform and its application in teaching. 10th International Conference on Software, Knowledge, Information Management \& Applications (SKIMA) (387-391). https://doi.org/10.1109/SKIMA.2016.7916252

Yokuş, G., \& Yanpar-Yelken, T. (2019). Designing online professional learning network for developing researcherly dispositions of pre-service teachers. International Journal of Social Sciences and Education Research, 5(3), 242-256. https://doi.org/10.24289/ijsser.542112

Zielinski, D. (2000). Can You Keep Learners Online? Training, 37(3), 64-75 https://doi.org/10.1037/h0087816

Published by OmniaScience (www.omniascience.com) Journal of Technology and Science Education, 2022 (www.jotse.org)

\section{(c) (1) (8)}

Article's contents are provided on an Attribution-Non Commercial 4.0 Creative commons International License. Readers are allowed to copy, distribute and communicate article's contents, provided the author's and JOTSE journal's names are included. It must not be used for commercial purposes. To see the complete licence contents, please visit https://creativecommons.org/licenses/by-nc/4.0/. 